\title{
Late Permian continental sediments in the SE Iberian Ranges, eastern Spain: Petrological and mineralogical characteristics and palaeoenvironmental significance
}

\author{
M. Isabel Benito ${ }^{\mathrm{a}, *}$, Raúl de la Horra ${ }^{\mathrm{a}}$, José F. Barrenechea ${ }^{\mathrm{b}}$, José López-Gómez ${ }^{\mathrm{a}}$, \\ Magdalena Rodas ${ }^{b}$, Jacinto Alonso-Azcárate ${ }^{c}$, Alfredo Arche ${ }^{a}$, Javier Luque ${ }^{b}$ \\ a Departamento de Estratigrafía, Instituto de Geología Económica, Facultad de Ciencias Geológicas, Universidad Complutense de Madrid, \\ 28040-Madrid, Spain \\ ${ }^{\mathrm{b}}$ Departamento de Cristalografía y Mineralogia, Facultad de Ciencias Geológicas, Universidad Complutense de Madrid, \\ 28040-Madrid, Spain \\ ${ }^{\mathrm{c}}$ Facultad de Ciencias del Medio Ambiente, Fábrica de Armas, Universidad de Castilla-La Mancha, 45071-Toledo, Spain
}

\begin{abstract}
A detailed mineralogical and petrological study and the analysis of paleosol profiles in continental alluvial sediments of the Late Permian in the SE Iberian Ranges (Spain) allow us to infer the significant environmental changes that occurred during this time period. Three parts have been distinguished in the Late Permian sediments (Alcotas Formation). The lower part includes abundant and well-preserved carbonate paleosol profiles and fine-grained sediments made up by quartz, feldspar, hematite and illite, with scarce kaolinite. The preservation of dolomicrite in some paleosols suggests that they originally developed as dolocretes in an arid to semi-arid climate with marked seasonality.

A change towards more humid and acid conditions can be deduced from the presence of siderite and goethite in paleosols in the middle part of the Alcotas Formation. Moreover, the presence of plant remains, coal beds and/or carbonaceous shales at the top of the middle part, and the lack of carbonate paleosols in the upper part of the formation would indicate a further step towards acid conditions. These conditions would increase until the Early Triassic, as indicated by the lack of carbonates and the presence of Sr-rich aluminium phosphate sulphates (APS minerals) at the base of the Triassic (Cañizar Formation), which clearly indicates extreme acid conditions during the Permian-Triassic transition of the study area.
\end{abstract}




\section{Introduction}

During the Permian-Triassic transition, dated at $251 \mathrm{Ma}$ (Menning, 2001), the Earth experienced the most severe crisis in its history. Both marine and terrestrial life suffere this crisis and it is estimated that $93-95 \%$ of all marine species (Raup, 1979) and ab॰ut 70\% of all vertebrate families (Maxwell, 1992) disappeared, which is twice as many groups as at the end-Ordovician marine mass extinction and many more than during the end-Cretaceus event.

Although the Permian-Triassic transition mass extinction and its possible causes are receiving far more attention now than in past decades, there are still controversies abøut the origin of the interrelated precesses that resulted in that crisis. Furthermore, Late Permian sediments below the Permian-Triassic Boundary (PTB) already show clear evidence of stepwise mass extinctions (Stanley and Yang, 1994; Wignall et al., 1998; Kozur, 1998; Jin et al., 2000; Benton, 2003), which could support the idea of linked causes.

Interpretations about this crisis are not equally clear in all the Late Permian rocks since those of marine origin show more pale»nt॰løgical evidence. As adequate correlation between rocks of marine and continental origin has not been established for the PTB, it is difficult to determine whether the terrestrial events were exactly contemporaneous with those in the oceans. Studies of the continental record are crucial for determining whether the mechanisms of the crisis and extinction are the same as those -bserved in the marine record. Although there is growing evidence that tetrapeds and insects alsø suffered considerable extinction, and that plant assemblages provide additional evidence of severe disturbance (Erwin, 1996), the gechemical and mineraløgical respønse to the crisis on land was prøbably different from the one recorded in marine sediments. Detailed geochemical and mineralegical analysis such as those of Hølster and Magaritz (1992), Retallack (1999), Krull and Retallack (2000) and Beauchamp and Baud (2002) may produce the key for a better understanding of the Permian-Triassic transition from a gløbal perspective.

This paper intends to contribute to the better understanding of the environmental changes by means of the mineraløgical characterization of fine-grained sediments and paleos $\bullet$ prøfiles of the continental Late Permian rocks of the SE Iberian Ranges, eastern Spain. A detailed study of a series of selected sections in a very complete succession of rocks in this area allows us to identify the changing mineral compesition across this transition. These variations are discussed in terms of palaeenvironmental changes and they are related to the mineralogical assemblages described in $\bullet$ ther regions.

\section{Geological setting}

During Late Permian-Early Triassic Iberia was a microplate located in the eastern part of Pangea in equatorial latitudes (Ziegler, 1990; Ziegler and Stampfli, 2001). By this time the western propagation of the Neotethys and the strike-slip motion of the Pyrenean and Gibraltar fault zones produced an extensional regime in the microplate, resulting in the creation of several extensional basins: the Iberian, Catalan and Pyrenean basins (Fig. 1).

The data presented in this paper have been -btaine from the Permian-Triassic transition røcks -f the southern Iberian Range. The present-day Iberian Range is a linear structure of Tertiary origin in central-eastern Spain, created by tectonic inversion of the Mesø zøic Iberian Basin during compressiønal tectonic events mainly during the Late Oligecene-Early Miøcene (Muñøz and Casas, 1997), which resulted in thin-skinned deformation with the detachment level in the evaporitic Keuper facies. The long and complex extensional story of the Iberian Basin started during the Early Permian with the extensional collapse of the Hercynian belt and westward propagation of the Netethys, and continued during the Late Permian and the Triassic (Søpeña et al., 1988; Ziegler, 1990; LópezGómez et al., 1998).

As in the rest of the basins of the Iberian microplate, the Upper Permian-Løwer Triassic rocks in the Iberian Basin are represented by alluvial sediments that lasted until Anisian times, when the Tethys Sea reache (Landete Formation) the eastern Iberian microplate margin (Fig. 2) (Arche and LópezGómez, 1999). The PTB is not represented in the study area. It is probably located somewhere from the contact between the lower and upper conglømerate subunits of the Høz de Gallø Formation to the lower 

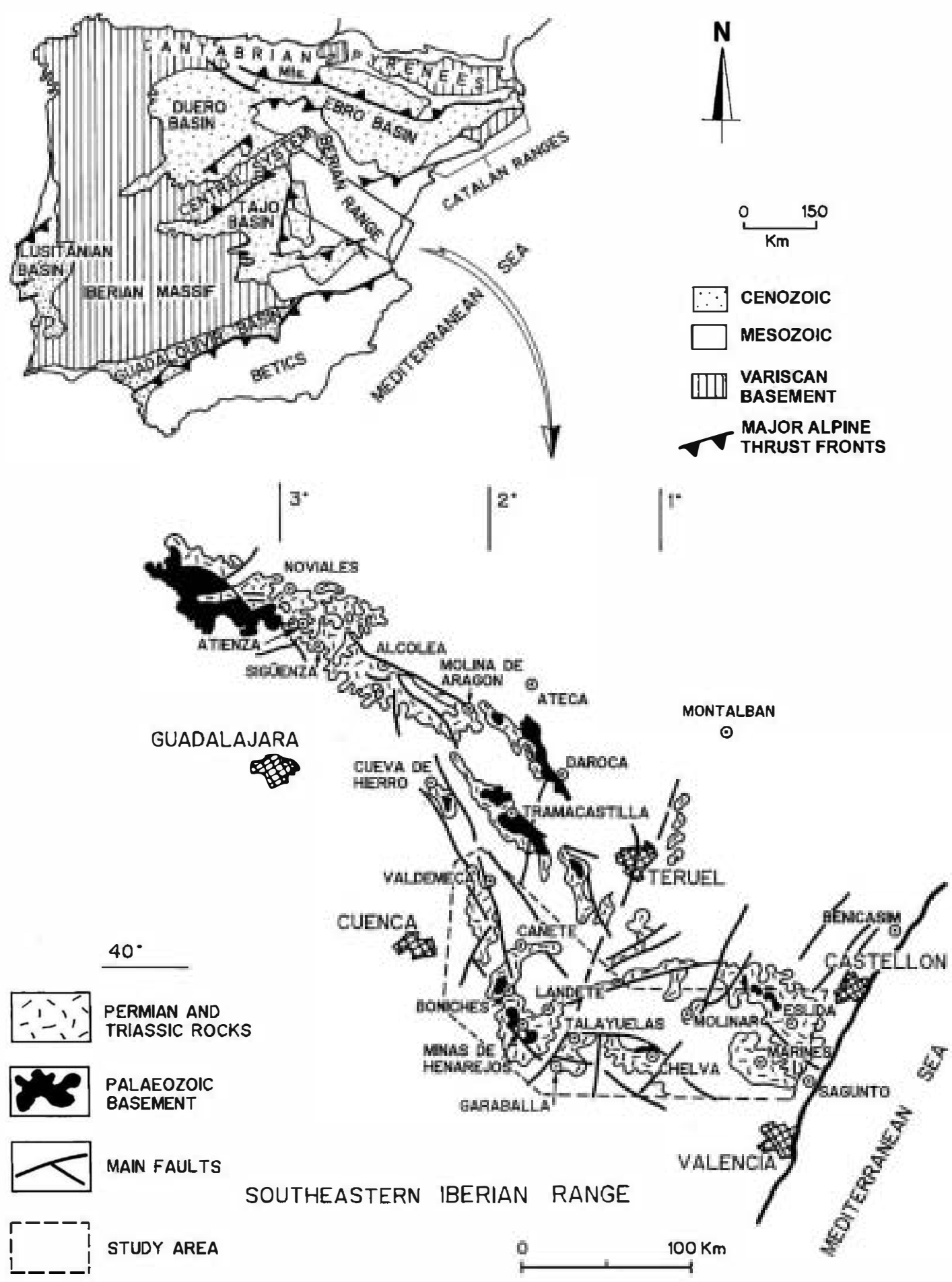

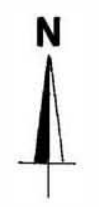

$\underbrace{150}_{\mathrm{Km}}$

CENOZOIC

MESOZOIC

VARISCAN

BASEMENT

MAJOR ALPINE

THRUST FRONTS
TALBAN

○

Fig. 1. Geographical and geological setting of the study area. Upper part shows the present-day main Cenozoic and Mesozoic basins and ranges and the major alpine thrust fronts. 


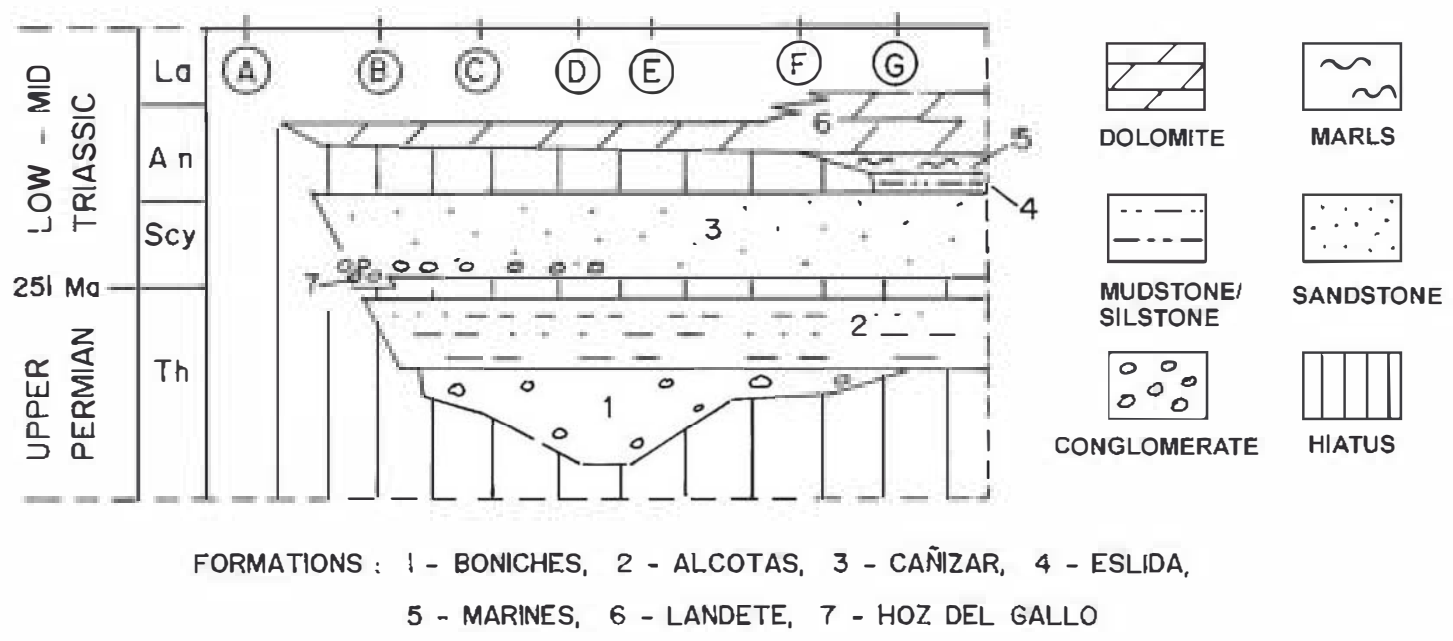

Fig. 2. Temporal and spatial range of the Permian-Triassic transition formations in the SE Tberian Ranges. Locations: A-North Valdemeca, B-South Valdemeca, C-Boniches, - Henarejos, E-Talayuelas, F-Chelva, G-Molinar. See Fig. 1 for the location details.

part of the Cañizar Formation (Fig. 2) (López-Gómez et al., 2005). Sedimentation in the basin was controlled and isølated by different highs that crossed the basin until the end of the Permian when most of the highs were covered by alluvial sediments, very near to the Permian-Triassic transition.

The present study is based on a detailed analysis of the Alcotas Formation (Late Permian) and the base of the Cañizar Formation (Early Triassic) as exposed in six stratigraphic sections (Bøniches, Landete, Talayuelas, Garaballa, Chelva and Chóvar-Eslida) from the study area (Fig. 3).

\section{Analytical methods}

Før the mineralogical analysis 54 samples of red siltstones and mudstones were collected from the Alcotas and Cañizar Formations near the PermianTriassic boundary (Fig. 3). The bulk sample mineral- gy was $\bullet$ btained by X-ray diffraction (XRD) after grinding and homegenization of the samples to $<53$ $\mu \mathrm{m}$. Random-øriented powders were examined on a Siemens Kristalløflex 810 diffractometer, using $\mathrm{Cu}$ $\mathrm{K} \alpha$ at $40 \mathrm{kV}$ and $40 \mathrm{~mA}$, a step size $\bullet 0.03(\bullet 20)$, and time per step of $1 \mathrm{~s}$ (scan rate of $1.8^{\circ} 2 \theta / \mathrm{min}$ ). The clay mineral compesition was determined on oriented aggregates of the $<2 \mu \mathrm{m}$ fraction $\bullet$ btained by sedimentation from an aqueous suspension ont glass slides. In søme cases they were subjected to thermal treatment at $550^{\circ} \mathrm{C}$ for $2 \mathrm{~h}$ and to solvation with ethylene glyc $(\mathrm{EG})$. A slower scan rate $\left(1.2^{\circ} 20^{\circ}\right.$ min) was used between $2^{\bullet}$ and $13^{\bullet} 20$ in order to get better-define peaks. Semi-quantitative analyses were performed following the methød prop»sed by Schultz (1964).

In order to determine the intensity of the postsedimentary processes that affected these samples, the full-width-half-maximum (FWHM) of the illite $10 \Delta$ reflection (the s-called Kübler index, KI) was measured on the diffractograms of the $<2 \mu \mathrm{m}$ material. Our data $(y)$ were transformed to Crystallinity Index Standard (CIS) data ( $x$ ) (Warr and Rice, 1994) by the formula: $y=\mathbf{0 . 8 6 9} x+\mathbf{0 . 0 0 2 2}$. Therefore, KI values quoted in the following parts of this study have been converted to the CIS scale, in which the anchizøne limits are $0.25-0.42^{\bullet} \Delta 20$.

Petrographic micrøscopy was used for the study of thin sections to complement the mineralogical characterization of the samples. A more detailed study of the textural and morphological features of the minerals was performed on gold-coated chips of selected samples in a Je» 6400 scanning electrøn micrøscope (SEM), equipped with an energy dispersive spectrmeter (EDS).

Anıther 53 samples have been used for a petrographic and geochemical study of sedimentary and diagenetic features of paleøsøls, using standard petrøgraphic techniques and cathodoluminescence, combined with an elemental analysis of carbonates. For 

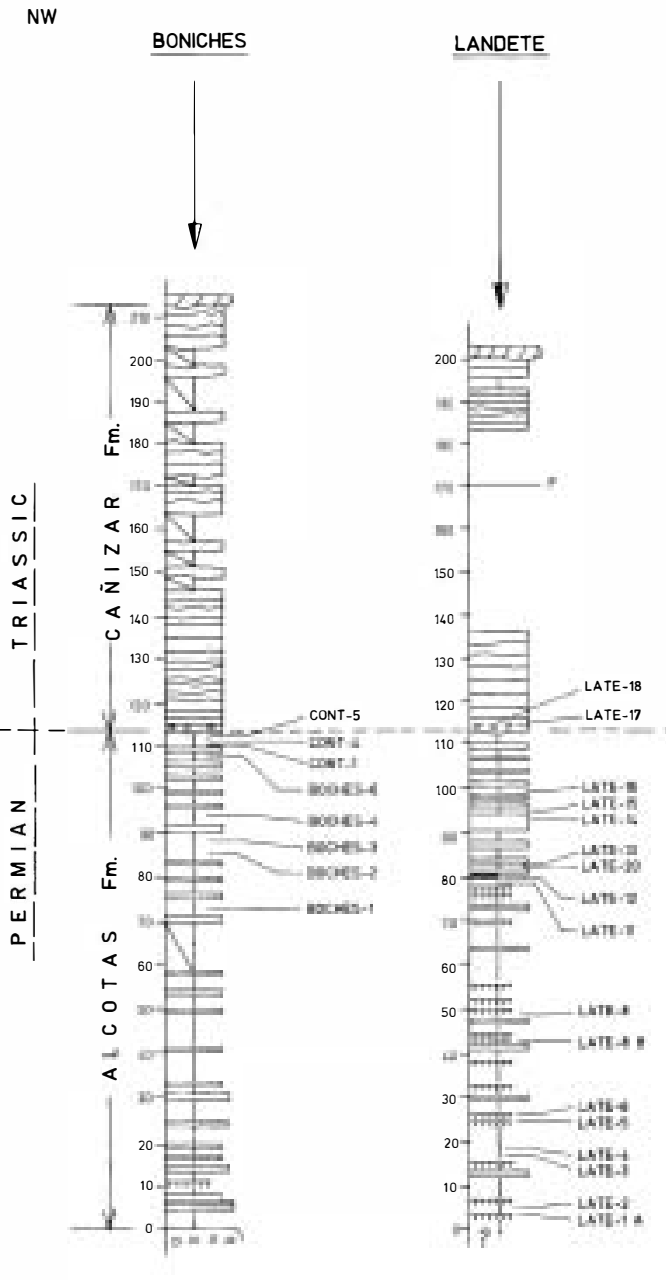

TALAYUELAS

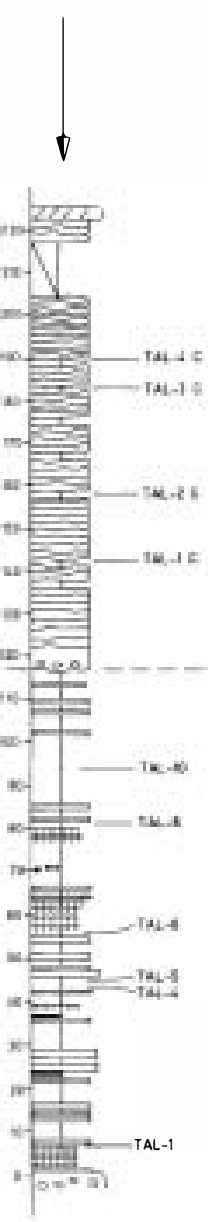

GARABALLA

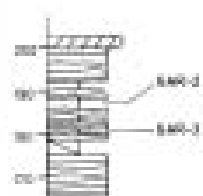

$=1$

믈

20

$=-$

$n$

$=$

$=$

- $2-106$

-

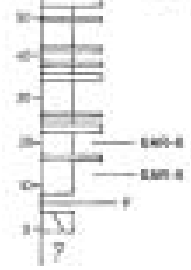

LEOENO

in anem

1200-4ext of

sE

- Tivero

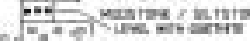

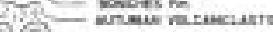

- mecover ealemor
CHELVA

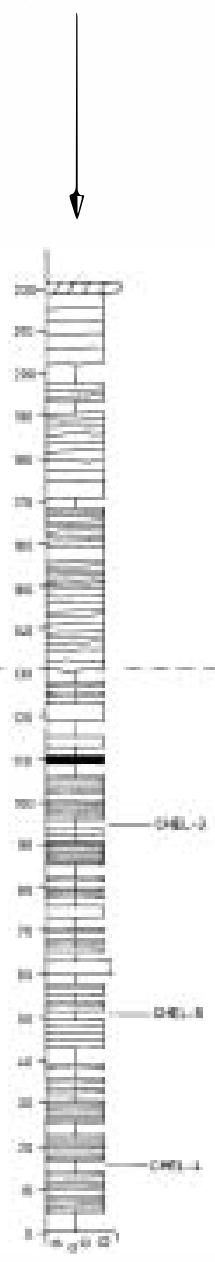

CHOVAR-ESLIDA

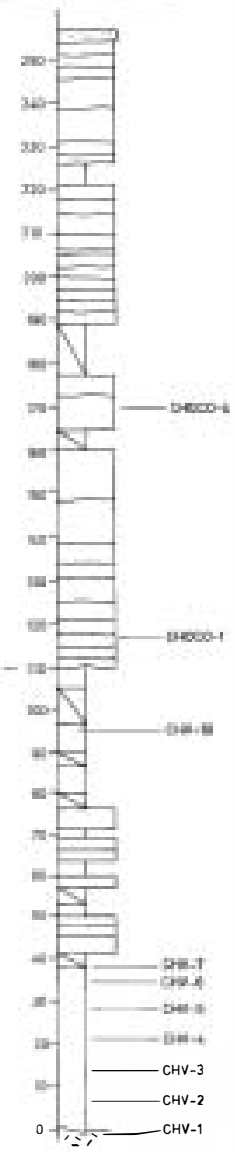

Fig. 3. Studied stratigraphical sections and location of the analysed samples. See Fig. 1 for the location of the sections. 
each sample, a polished and uncovered thin section was prepared to $30 \mu \mathrm{m}$ thickness for petrographic and gechemical analysis. Cathodøluminescent (CL) examination was carrie $\bullet$ ut using a Technosyn ${ }^{\bullet}$ cold cathødøluminescent unit. Folløwing examination with CL, all thin sections were stained with Alizarin Red S and pøtassium ferricyanide (Dicksøn, 1966). Elemental analysis for $\mathrm{Ca}, \mathrm{Mg}, \mathrm{Sr}, \mathrm{Mn}$, and Fe was performed on a JEOL JXA-8900 M WD/ED electron micrøprobe. All analyses were conducted with an accelerating voltage of $15 \mathrm{kV}$ and a spot size of $5 \mu \mathrm{m}$. Detection limits were $100 \mathrm{ppm}$ for $\mathrm{Mg}, 250 \mathrm{ppm}$ for Sr, 200 ppm for Mn, and 250 ppm for Fe, and 140 ppm for Na.

\section{The sediments}

\subsection{Depositional environments and age}

Subsidence reconstructions (Arche and LópezGómez, 1996; Van Wees et al., 1998; Vargas, 2002) show that the Permian-Triassic extensional period can be subdivided inte four distinct episødes bounded by angular unconformities or hiatuses. In this paper we only deal with sediments of the second and third episødes.

Early Permian: Represented by andesitic-basaltic volcanic rocks and dykes asseciated with lacustrine and fluvial sediments in iselated basins along the Iberian Range (Hernand• et al., 1980; Doblas et al., 1993; Lage et al., 2001, in press).

Late Permian: Represented by red bed facies: conglomerate, sandstone and mudstone, usually known as "Saxønian facies" in the literature (Søpeña et al., 1988; Arche and López-Gómez, 1996). They were depesite in a bread asymmetric rift basin trending NW-SE. The episode ended with uplift and partial erosion.

Late Permian-Middle Triassic: Represented by the continental Buntsandstein facies and the shallow marine Röt and lower part of the Muschelkalk facies, deposited in a single rift basin (Søpeña et al., 1988; López-Gómez and Arche, 1993).

Middle Triassic-Early Jurassic: Represented by shallow marine carbønates and evapørites (Pérez-Arlucea and Søpeña, 1985; Ortí, 1987; Ortí et al., 1996; López-Gómez et al., 1998; Gómez and Gøy, 1999).
The Late Permian sediments of the secønd episøde are represented by the Bøniches and Alcotas Formations (Fig. 2) (López-Gómez and Arche, 1993). This paper focuses on the Alcotas Formation and the base of the Cañizar Formation (Early Triassic).

The Alcotas Formation (López-Gómez and Arche, 1993), up to $170 \mathrm{~m}$ thick, consists of red to dark brown siltstone and mudstone layers and lenticular bodies of sandstone and locally conglomerate. The formation has been interpreted as deposits of seasonal braided rivers with high avulsion rate and extensive floodplains and shallow semi-permanent lakes that evelved towards the top to meandering rivers. Several pøllen and spore assemblages of Late Permian (Thüringian) age have been found in the lower and middle parts of the Formation (Døubinger et al., 1990; Søpeña et al., 1995).

The third episøde has a very complex vertical and horizontal facies distribution and it is constituted by the Høz de Gallø Formation and the Cañizar Formation. The Hoz de Galle Formation (Ramos, 1979; Ramos et al., 1986) only crops out in the NW area where it reaches up to $4 \mathrm{~m}$ thick (Fig. 2). It consists of quartzite

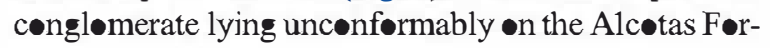
mation or on the Løwer Paleøzic basement.

The Cañizar Formation (López-Gómez and Arche, 1993) is up to $170 \mathrm{~m}$ thick and consists of pink to white arkese with minør conglømerate and red mudstone layers. It has been subdivided int six subunits by means of regional erosion surfaces and interpreted

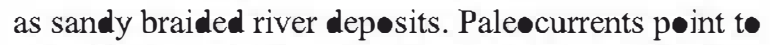
the SE. It lies conformably on the $\mathrm{H} \bullet z$ de Gallø Formation or unconformably on the Alcotas Formation (Fig. 2).

\subsection{Mineralogy of the fine-grained sediments}

The results of the mineraløgical characterization are presented in Table 1. Most of the samples analysed in the Alcotas and Cañizar Formations contain small angular to subrounded quartz and albite grains in a matrix composed of illite and hematite (Fig. 4a). Ka॰linite has been detecte in twø samples frøm the Chelva section and small amounts of a chlørite/smectite mixedlayer are recognised in one sample from the Landete section by a reflection at $34.5 \AA$, which shifts to $36.1 \AA$ up॰n ethylene-glyc strontium-rich aluminium phosphate sulphate minerals (gøyazite/svanbergite) are detected on XRD traces of 
Table 1

Variation in the mineralogical composition and Kübler index data (KI) of the samples collected along the studied cross-sections

\begin{tabular}{|c|c|c|c|c|c|c|c|c|}
\hline Section & Sample & Qtz & Ill & Hem & $\mathrm{Ab}$ & $\mathrm{K} \ln$ & Prl APS & KI \\
\hline \multirow[t]{10}{*}{ Talayuelas } & TAL4C & $*$ & $* * * *$ & & $*$ & & & 0.44 \\
\hline & TAL3C & $*$ & $* * * *$ & & $*$ & & & 0.52 \\
\hline & TAL2C & $*$ & $* * * *$ & & & & & 0.60 \\
\hline & TAL1C & $*$ & $* * * *$ & & * & & & $\bullet .61$ \\
\hline & TALI & $* *$ & $* * * *$ & $*$ & * & & & n.d. \\
\hline & TAL\& & $* *$ & $* * * *$ & $*$ & $*$ & & & 0.75 \\
\hline & TAL6 & $* *$ & $* * * *$ & $*$ & $*$ & & & 0.50 \\
\hline & TAL5 & $* *$ & $* * * *$ & $*$ & $*$ & & & 0.50 \\
\hline & TAI.4 & $* *$ & $* * * *$ & & $*$ & & & 0.49 \\
\hline & TALl & $* *$ & $* * * *$ & $*$ & $*$ & & & 0.57 \\
\hline \multirow[t]{9}{*}{ Boniches } & CONT5 & $* *$ & $* * * *$ & $*$ & $*$ & & & 0.75 \\
\hline & $\mathrm{CONT4}$ & $* *$ & $* * * *$ & $*$ & $*$ & & & 0.72 \\
\hline & CONT1 & $* *$ & $* * * *$ & $*$ & $*$ & & & 0.71 \\
\hline & B OCHES7 & $* *$ & $* * * *$ & $*$ & $*$ & & & 0.44 \\
\hline & B OCHES6 & $* *$ & $* * * *$ & $*$ & $*$ & & & 0.72 \\
\hline & B OCHES4 & $* *$ & $* * * *$ & $*$ & $*$ & & & $\bullet .61$ \\
\hline & B OCHES3 & $* *$ & $* * * *$ & $*$ & $*$ & & & 0.74 \\
\hline & BACHES2 & $* * *$ & $* * *$ & $*$ & $*$ & & & 0.66 \\
\hline & BOCHESI & $*$ & $* * * *$ & $*$ & $*$ & & & $\bullet .61$ \\
\hline \multirow[t]{3}{*}{ Chelva } & CHEL3 & $* *$ & $* * * *$ & $*$ & $*$ & & & 0.57 \\
\hline & CHEL5 & $* *$ & $* * *$ & $*$ & $*$ & * & & $\bullet .61$ \\
\hline & CHEL4 & $* *$ & $* * * *$ & $*$ & * & * & & 0.58 \\
\hline \multirow[t]{16}{*}{ Landete } & LATE18 & $* *$ & $* * * *$ & $*$ & $*$ & & & 0.65 \\
\hline & LATE 17 & $* * *$ & $* * *$ & & & & & 0.61 \\
\hline & LATE 16 & $* *$ & $* * * *$ & $*$ & $*$ & & & 0.58 \\
\hline & LATE15 & $* *$ & $* * *$ & $*$ & $*$ & & & 0.57 \\
\hline & LATE14 & $* *$ & $* * *$ & $*$ & $*$ & & & 0.63 \\
\hline & LATE2 & $*$ & $* * * *$ & & * & & & 0.55 \\
\hline & LATE12 & $*$ & $* * * *$ & & * & & & 0.50 \\
\hline & LATE11 & $* *$ & $* * * *$ & & $*$ & & & 0.67 \\
\hline & LATE\& & $* *$ & $* * * *$ & $*$ & $*$ & & & 0.55 \\
\hline & LATE\&B & $* * *$ & $* * *$ & $*$ & $*$ & & & $\bullet .61$ \\
\hline & LATE6 & $* * *$ & $* *$ & $*$ & $*$ & & & 0.70 \\
\hline & LATE5 & $* *$ & $* * * *$ & $*$ & $*$ & & & 0.71 \\
\hline & LATE4 & $* *$ & $* * * *$ & $*$ & $*$ & & & 0.72 \\
\hline & LATE3 & $* *$ & $* * * *$ & $*$ & & & & 0.55 \\
\hline & LATE2 & $* *$ & $* * * *$ & $*$ & $*$ & & & 0.67 \\
\hline & LATEIA & $*$ & $* * * *$ & $*$ & * & & & 0.62 \\
\hline \multirow[t]{7}{*}{ Garaballa } & GAR2 & $*$ & $* * * *$ & & * & & $*$ & 0.65 \\
\hline & GAR3 & $*$ & $* * * *$ & $*$ & $*$ & & $*$ & 0.65 \\
\hline & GAR4 & $*$ & $* * * *$ & $*$ & $*$ & & $*$ & 0.57 \\
\hline & GAR\& & $*$ & $* * * *$ & $*$ & $*$ & & $*$ & 0.51 \\
\hline & GAR7 & $*$ & $* * * *$ & $*$ & $*$ & & & $\bullet .65$ \\
\hline & GAR6 & $*$ & $* * * *$ & $*$ & * & & & 0.53 \\
\hline & GAR5 & $*$ & $* * * *$ & $*$ & & & & 0.62 \\
\hline \multirow[t]{7}{*}{ Chóvar } & $\mathrm{CH} \bigcirc \mathrm{C} 4$ & $* *$ & $* * *$ & $*$ & $*$ & & & 0.36 \\
\hline & CHOCOl & $* *$ & $* * * *$ & $*$ & * & & & 0.41 \\
\hline & CHVI0 & $* *$ & $* * * *$ & $*$ & $*$ & & & 0.28 \\
\hline & $\mathrm{CHV} 7$ & $* *$ & $* * *$ & $*$ & $*$ & & * & 0.36 \\
\hline & CHV6 & $* *$ & $* * *$ & $*$ & $*$ & & * & 0.32 \\
\hline & CHV5 & $* *$ & $* * *$ & $*$ & * & & * & 0.33 \\
\hline & CHV4 & $* *$ & $* * *$ & $*$ & $*$ & & $*$ & 0.40 \\
\hline
\end{tabular}

Table 1 (continued)

\begin{tabular}{|c|c|c|c|c|c|c|c|}
\hline Section & Sample & Qtz & Ill & Hem & $\mathrm{Ab} \mathrm{K} / \mathrm{n}$ & Prl APS & KI \\
\hline \multirow[t]{2}{*}{ Chóvar } & CHV2 & $* *$ & $* * *$ & $*$ & * & * & 0.34 \\
\hline & CHV1 & ** & $* * *$ & $*$ & * & & n.d. \\
\hline
\end{tabular}

Quartz (Qtz), hematite (Hem), albite ( $\mathrm{Ab})$ and goyazite/svanbergite (APS) contents were estimated from X-ray diffraction traces of unoriented mineral-aggregate samples, whereas illite (Ill), kaolinite $(\mathrm{Kln})$ and pyrophyllite $(\mathrm{Prl})$ contents were calculated from oriented aggregates of the $<2-\mu \mathrm{m}$ fraction. ${ }^{* * * *}$ Major phase, $(>50 \%$ in the semi-quantitative analyses), ***frequent phase $(20$ to $50 \%)$, **minor phase (10 to $20 \%$ ), *accessory phase $(<10 \%)$.

random-øriented pøwders from the Cañizar Førmation in the Garaballa section (Fig. 3). Zircon, ilmenite and xenotime are present as accessory minerals within this section. The Kübler index data for the Boniches, Landete, Talayuelas, Garaballa and Chelva sections range between $0.44^{\circ}$ and $0.75^{\circ} \Delta 2 \theta$ and are clearly indicative of diagenetic conditions.

Samples from the Chovar-Eslida section are red limølites with a similar mineraløgical compesition. However, the XRD analysis reveals the presence of pyrophyllite instead of ka linite in six of the sam-

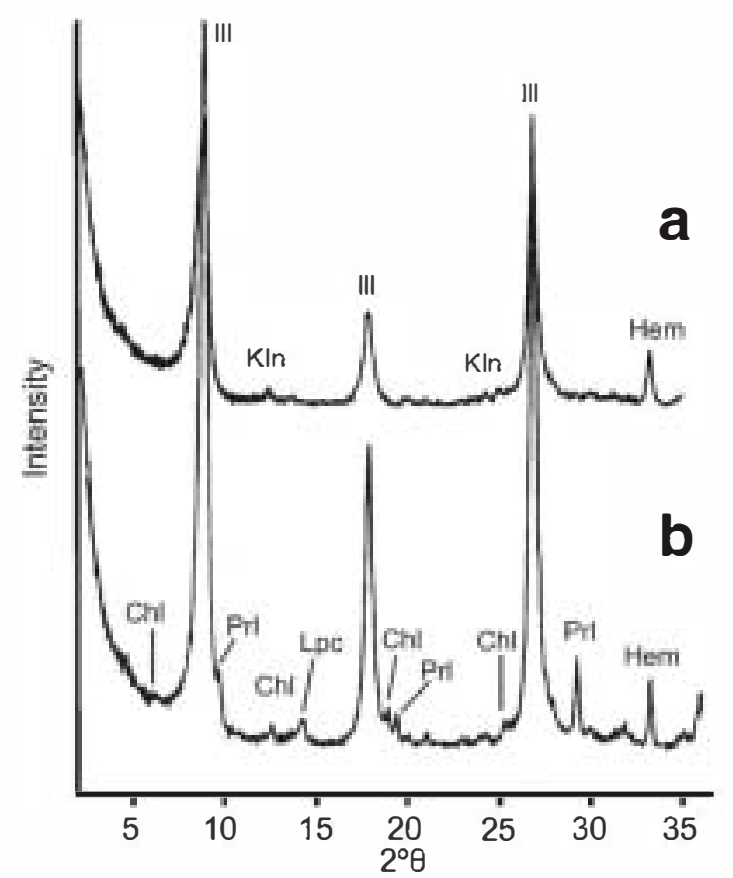

Fig. 4. XRD aces of oriented aggregates firom (a) sample CHEL-4, representative of siltstones composed by illite and kaolinite and (b) sample CHV5, with a clay assemblage constituted by illite and pyrophyllite. 
ples, together with traces of chlorite and lepidocrcite (Fig. 4b). This clay mineral assemblage, together with the lower $\mathrm{KI}$ data $\left(0.28-0.41^{\bullet} \Delta 20\right)$, suggests that these samples were subjected to very low grade metamorphism.

The SEM study reveals that illite in most of the sections is found as roughly oriented platy crystals within the matrix (Fig. 5a) or as small fibres coating larger crystals (Fig. 5b). In samples from the ChovarEslida section pyrøphyllite cømmønly $\bullet$ ccurs as packets of slightly deformed crystals (Fig. 5c).

\subsection{Paleosols description}

Paleosøls developed within the Alcotas Formation have been studied in detail in the western part of the study area, specifically in the Landete and Talayuelas stratigraphic sections (Figs. 3 and 6), where they are more abundant and best preserved. In the eastern part -f the study area (Chelva and Chóvar-Eslida stratigraphic sections), subsidence was bigher during the Late Permian (Vargas, 2002), and thus, paleosıls are

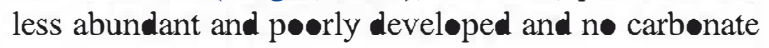
pale $\bullet$ ls have been $\bullet$ bserved. Carbønate søil prøfiles with different stages of development have been recønized in the Landete and Talayuelas sections (Fig. 6). They correspend to the categery of aridis $\bullet$ s and vertisøls propesed by Retallack (1993). In both sections the Alcotas Fornation can be subdivided inte three parts based on the presence or absence of palesøls, their type and stage of development and on the mineralıgical compesition (Fig. 6).

In the lower part paleosels are developed over alluvial sediments (Fig. 6) composed of red to brown sandstøne, siltstøne and mudstøne. Pedogenic prøfiles commonly range between $25 \mathrm{~cm}$ and $1.5 \mathrm{~m}$ thick and they vary in their stage of development from stage I to stage II of Machette (1985). The dark red mudstone and/or siltstone contain scattered and small spherical to subspherical carbønate nodules (up to $22 \mathrm{~mm}$ in diameter) and root traces of abøut $13 \mathrm{~cm}$ løng and $3-5 \mathrm{~cm}$ wide (Fig. 7a,b). Upwards in the profile, carbonate nodules are larger, up to $7 \mathrm{~cm}$ in diameter and, in søme prøfiles, they form continuous layers of cœalescing nodules that can be traced laterally at least $50 \mathrm{~m}$ (Fig. 7a). This calcareous hørizøn (15 t• $55 \mathrm{~cm}$ thick) has a dark re colour or, in søme cases, a mottled dark red to yelløwish colour and typically displays a very well developed cracking structure composed of abundant angular and irregular cracks (up to $1 \mathrm{~mm}$ thick) (Fig. 7c). The horizøn gradually passes upwards int॰ a purple to dark red clayey horizon (Fig. 7a) with evi-

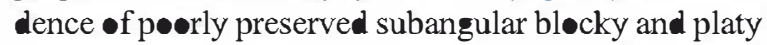
peds. Maximum thickness of this upper horizon is 50 $\mathrm{cm}$, with its top grading int the overlying red siltstone and mudstone or sharply truncated by bodies of sandstone. The mineralogy and texture of the original carbonate that precipitated in the calcareous horizons are not preserved in møst $\bullet$ the pale $\bullet$ ls because they are replace by coarse and euhedral to subeuhedral dolomite and magnesite that precipitated during subsequent stages of diagenesis (Fig. 7c). The carbonate precursor has been only observed in the Talayuelas section, where it is constituted by dolemicrite that shows dark red luminescence and nodular texture (Fig. 7c).

The middle part of the Alcotas Formation consists of dark red mudstone with thin bedies of sandstone

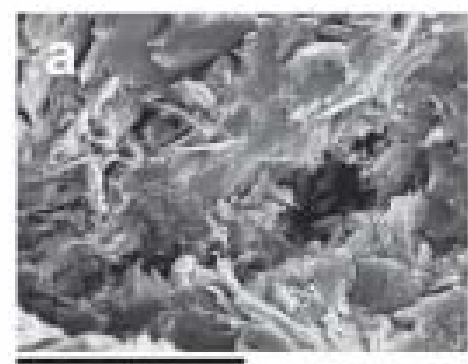

$30 \mu \mathrm{m}$

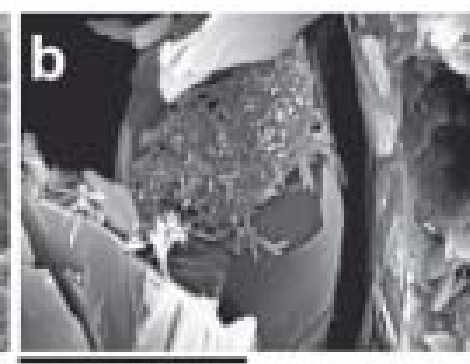

$6 \mu \mathrm{m}$

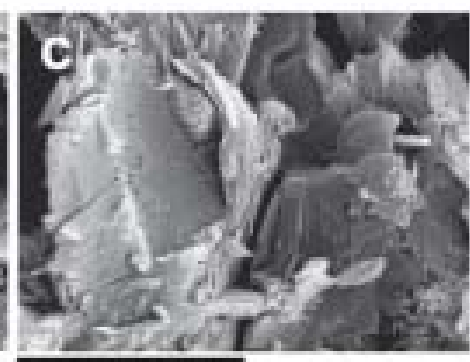

$7 \mu \mathrm{m}$

Fig. 5. SEM images of(a) roughly oriented illite (ill) platy crystals within the matrix; (b) small fibers of illite (ill) coating larger mica crystals; (c) stacks of slightly deformed crystals of pyrophyllite (prl). 


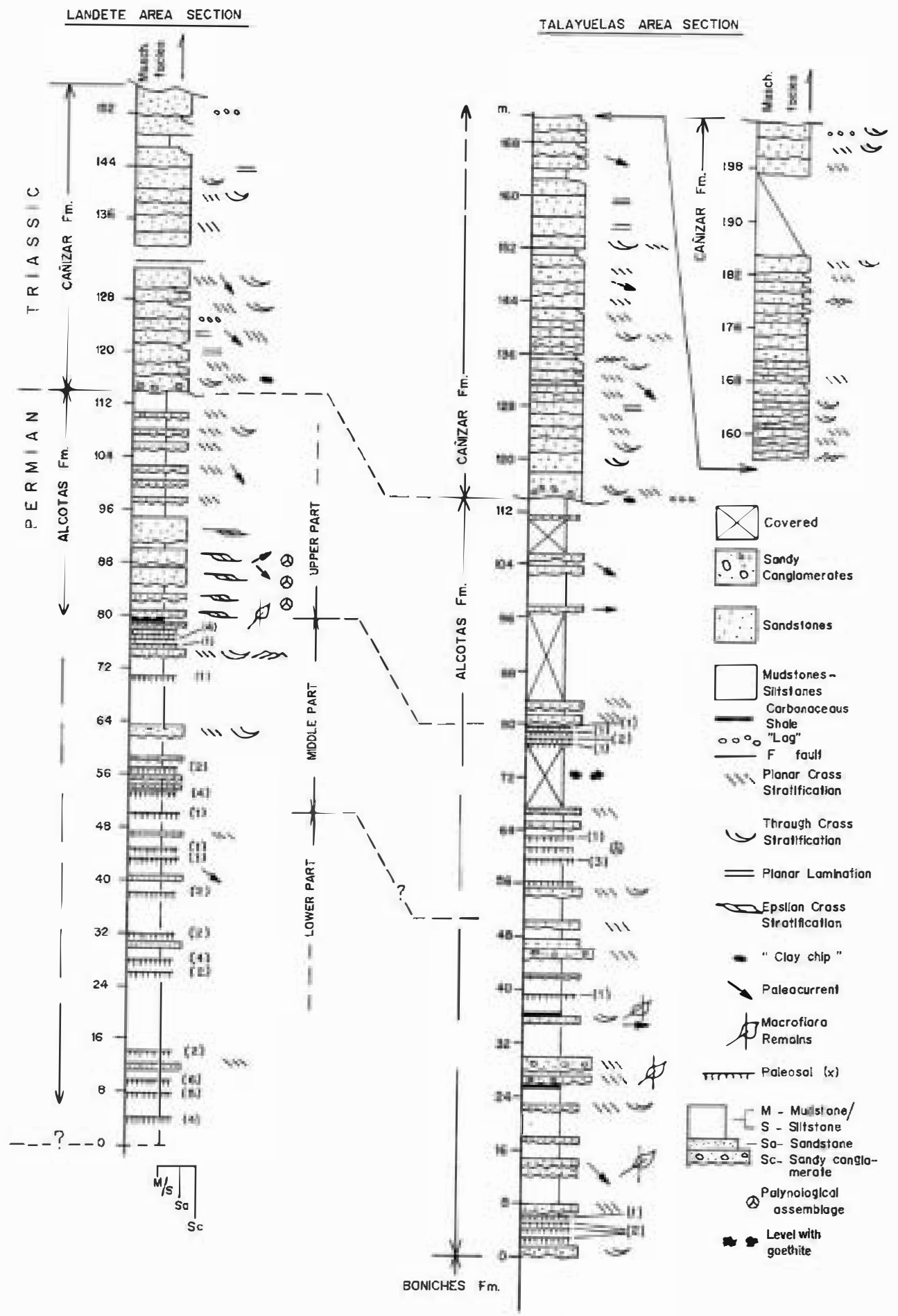

Fig. 6. Landete and Talayuelas sections in detail. Three parts (lower, middle and upper) have been differentiated in both sections by means of their mineralogical and perological data and paleosols features. Figures in brackets indicate the number of studied samples in each paleosol. 
interbedded (Fig. 6). In this part, pale $\bullet$ ls vary frøm stage I to IV according to Machette's (1985) classification. Pale $\bullet$ horizons formed in the middle part of the sequence are similar to those of the lower part of the Alcotas Formation, althøugh they can be better developed (stage IV of Machette's classification) with a maximum thickness of $1 \mathrm{~m}$ (Fig. 7d). The calcareus horizon of these paleosøls is composed of fermginøus mudstone that shows a lower part with coalescing carbønate nodules and an upper part, up to $20 \mathrm{~cm}$ thick, $\bullet$ f sid brøwnish tø yelløwish carbønate with a sharp top and lateral continuity that can be traced for $100 \mathrm{~m}$. It exhibits a weakly developed platy structure and abundant irregular cracks, asseciated with fossil røot traces (Fig. 7c). The original mineraløgy of the calcareous paleos 1 horizons developed in the middle part $\bullet$ the Alc $\bullet$ tas Formation are not preserved because they were completely replace by coarse dolomite and magnesite that precipitated during early stages of burial and obliterated the original pedogenic microstructure. In addition, these paleosels are affected by fractures that developed during late stages of burial. These fractures are fille by ankerite, barite and/or ferrøan calcite.

The last tw॰ pale $\bullet$ s $\bullet$ bserved in the middle part $\bullet$ the Landete section contain tw॰ beds: the løwer bed (up to $20 \mathrm{~cm}$ thick) is composed of mudstone or sandstone largely replace by magnesite; the upper bed is a very dark layer, up to 7-10 cm thick, mainly composed of goethite, which preserves lenticular pseudomorphs of siderite, up to $7 \mathrm{~mm}$ løng, that form aggregates (Fig. $7 \mathrm{e}-\mathbf{g})$. Only small relics of siderite $\left(\mathrm{Ca}_{0 .{ }_{2}} \mathrm{Mn}_{\mathbf{0}} \cdot 12\right.$ $\mathrm{Fe}_{0.80} \mathrm{Mg}_{0.06} \mathrm{CO}_{3}$ ), less than $10 \mu \mathrm{m}$ wide, are preserved in the pseudomorphs. Geethite may replace siderite crystals completely. More commonly, siderite pseudomørphs are constituted by gøethite, calcite and ankerite (Fig. 7f, g). In this case, goethite precipitation mimics the external lenticular shape and the cleavage planes of the siderite precursor (Fig. 7g); the remaining poresity inside the pseudomorphs is filled by ankerite and ferrøan calcite (Fig. 7g). Ankerite and calcite als• fill fractures that postdate siderite and goethite precipitation (Fig. 7f).

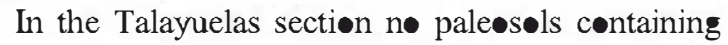
siderite or siderite pseudomorphs have been recognized in the middle part of the sequence. However, accumulations of goethite precipitated around fossil plant fragments have been observed along søme partially covered stratigraphic beds (Fig. 6).
The upper part of the Alcøtas Førmation cøntains dark orange to red mudstone and sandstone with n॰ evidence of pedogenic carbonate precipitation (Fig. 6). The only preserved pedogenic features correspond to søme diffuse, drab coløured (greenish-grey) haløes possibly developed around reduced root channels (Retallack, 1997). The base of the upper part of the Alcotas Formation in the Landete section is constituted by greenish to reddish lutites interbedded with carbnaceous shales (Fig. 7h). In addition, there are some thin and discontinuous layers, up to $1 \mathrm{~cm}$ thick, composed of siderite pseudomorphs, which are interbedded with the carbonaceous shales. Carbonace us shales and/or coal beds similar to those of the Landete section have been observed in the upper part of the Alcotas Formation in the Chelva stratigraphic section (Fig. 3).

\section{Discussion}

Mineraløgical studies may result in a key-toøl for a better understanding of the palaeenvironmental changes recorded during the poorly known PermianTriassic transition in continental sediments. The SE

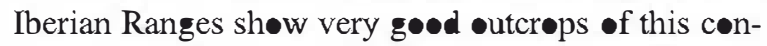
tinental transition. A detailed mineral $\bullet$ gical study from a combination of both fine-grained samples and søil profiles allows us to determine some of the main characteristics of the Late Permian general changes and their possible origin and consequences.

\subsection{Mineralogical composition of the fine-grained sediments}

The clay mineral assemblage of most of the Permian-Triassic sediments of the SE Iberian Ranges is formed predominantly by illite (with KI values that are characteristic of diagenesis) and minor amounts of ka॰linite in some of the samples. However, the narrower $10 \AA$ peaks measured in the Chovar-Eslida section $\left(0.28-41^{\bullet} \Delta 2 \theta\right)$ and the presence of pyrphyllite in some samples indicate that very low grade metamorphic conditions were attained in the area. The very low grade metamorphic clay assemblage is described for the first time within the SE Iberian Range. Preliminary data suggest that extensional tectonics and crustal thinning, combined with an॰maløusly high subsidence rates (Van Wees et al., 

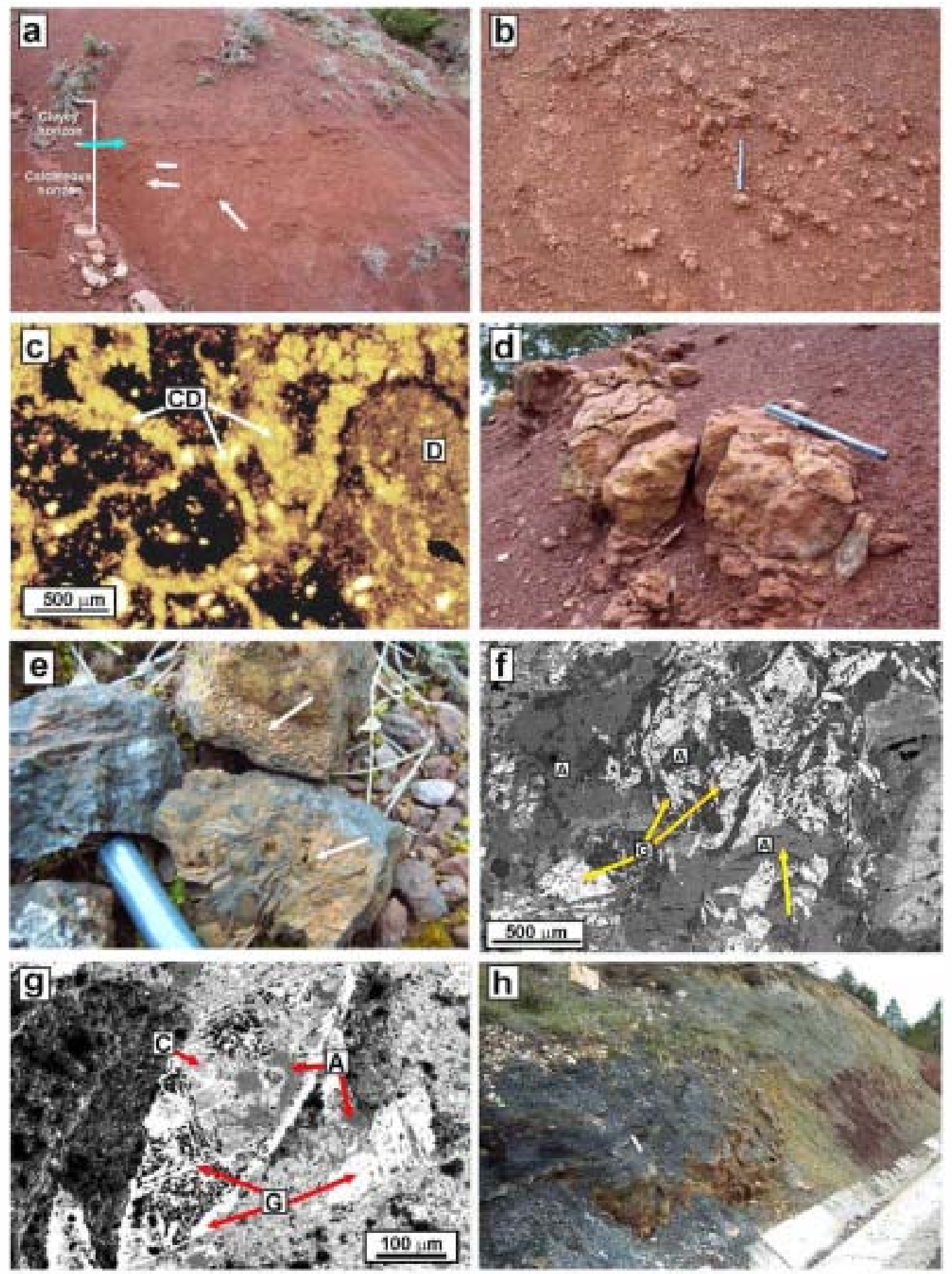
1998; Vargas, 2002) are respønsible for the develøpment of the metamorphism. The extent of this anchimetamorphic event is currently under evaluation.

The presence of illitic clay as the predominant component of the fine-graine siliciclastic continental sediments is in agreement with previous studies -f the Western European Permian-Triassic (Lucas, 1962; Fisher and Jeans, 1982; Lippmann and Berthøld, 1992; Jeans et al., 1994; Ruiz Cruz, 1996; Marfil et al., 1996). Lindgreen and Surlyk (2000) found a more complex clay assemblage in the Permian-Triassic mudstone of East Greenland, with illite, chlorite, vermiculite and illite-smectite. The authors argued that discrete clay minerals in these rocks are largely detrital, derive from weathered Precambrian and Caledonian crystalline basement of Greenland.

In a study $\bullet$ Permian-Triassic røcks of the Alcaraz region (Spain), Søuth Devon coast (U.K.), and deep wells in the Western Approches and Yorkshire, Jeans et al. (1994) conclude that much of the clay mica assemblage was formed originally in coeval deserts, and it was then eroded and deposited as detritus in adjacent areas. They claim that the ferric nature of the micas and the abundance of clay mica in the uppermost layers of søils from present-day arid regiøns support this assertion. Alternatively they suggest that much $\bullet$ the clay mica could have been wind transported from søurces outside Europe. This wind-blown hyp thesis was als considered in a previøus work $\bullet$ n the study area by Aløns-Azcárate et a1. (1997) wh॰ suggested the Zechstein Basin (P•land) as the pøtential søurce area. Many of the arguments concerning the prevailing oxidizing conditions and clay mica development in søils of arid or semi-arid regiøns might apply to $\bullet$ ur samples.

\subsection{Paleosol interpretation}

The original carbonate mineralıgy of most of the calcareous horizons developed in the lower part of the Alcotas Formation is uncertain because they are largely replace by coarse dolomite and/or magnesite. These mineral assemblages are similar to those precipitated in the red beds of the Late Permian of Austria (Spötl and Burns, 1994). However, the preservation of dolømicrite in some horizons (Fig. 7c) suggests that they originally developed as doløcretes in an arid to semi-arid climate with marked seasonality (Wright and Tucker, 1991; Spötl and Wright, 1992; Alıns -Zarza, 2003).

It is not possible to determine the original miner-

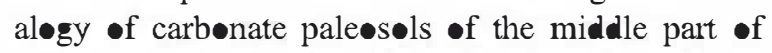
the Alcotas Formation, because they are replaced by coarse magnesite and n๑ relict of the carbonate precurs $\bullet$ has been preserved. However, early diagenetic siderite has been observed in the dark bed developed at the top of these paleosøls, just below and interbedded with the carbonaceus shales at the base of the upper part of the Landete section (Figs. 6 and $7 \mathrm{~h}$ ). Siderite has very low $\mathrm{Mg}$ and $\mathrm{Ca}$ and high Mn contents that are typical of siderites precipitated from meteoric-derived waters (Møzley, 1989). Siderite precipitation has been widely described as a very early diagenetic phase that commonly occurs in organic-rich marsh and swamp sediments deposited in floodplains and deltas (Cøleman, 1985; Curtis and Cøleman, 1986; Homibreok and Lengstaffe, 1996; Mackay and Longstaffe, 1997; Morad, 1998; Rossi et al., 2001, for example). Morever, siderite precipitation requires very low $p \boldsymbol{\bullet}_{2}$, very high $p \mathrm{C} \boldsymbol{\Theta}_{2}$, a slightly acid to near neutral $\mathrm{pH}$, and high concentrations of

Fig. 7. (a) Carbonate soil profile

(white arrows). (b) Detail of the carbonate nodules developed in the lower part of the Alcotas Formation. The pen for scale is $14 \mathrm{~cm} \mathrm{long}$. (c) Photomicrograph of a paleosol of the lower part of the Talayuelas section. Note nodulized dolomicrite (D) to the right, and the cracking structure, now replace by coarse dolomite (CD), to the left. (d) Calcareous horizon of a soil profile

The pen for scale is $14 \mathrm{~cm}$ long. (e) Goethite replacing siderite aggregates developed in paleosols of the middle part of the Landete section. Note the presence of abundant lenticular pseudomorphs of siderite (arrows). The cap of the pen for scale is $3 \mathrm{~cm}$ long. (f) Backscattered SEM imagine of a siderite pseudomorphs aggregate. Note that goethite $(G)$ preserves the extemal morphology of the siderite precursor. Ankerite (A) subsequently precipitated in the inner and outer part of the pseudomorphs and in fractures that affect aggregates (yellow arrow). (g) Backscattered SEM images of a siderite pseudomorph. Note that goethite $(\mathrm{G})$ preserves the external morphology of the crystal and mimics the original cleavage of the siderite precursor. Ankerite (A) and calcite (C) subsequently precipitated in the inner and outer part of the pseudomorph. (h) Aspect of the upper part of the Alco Formation. The red beds (right of the photograph) are overlain by sandstone and carbonaceous shale (left). The scale bar is $15 \mathrm{~cm}$ long. 


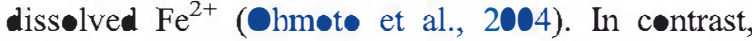
pedogenic dolømite commonly •ccurs in well-aerated soils, and its precipitation requires relatively low $\mathrm{pCO}_{2}$ (Wright and Tucker, 1991), and higher $\mathrm{pH}$ (Krumbein and Garrels, 1952) and $\mathrm{Mg}+\mathrm{Ca} / \mathrm{Fe}$ ratiøs (Cøleman, 1985; Curtis and Cøleman, 1986) than siderite precipitation. Thus, the environmental conditions likely changed towards more humid and acid during formation of siderite beds, which precipitated in peorly aerated and peorly drained areas. These environmental conditions agree with the presence of the carbonaceous shales and coal beds in the base of the upper part of the Landete section, and the type of plant remains of these levels that indicate a change towards more humid conditions (Diéguez and Barron, 2005).

Siderite is largely or completely replaced by gøethite that precipitates under oxidizing conditions when siderite becomes unstable. Gøethite is postdated by ankerite and calcite that precipitated during later stages of diagenesis (Fig. 7f, $\mathbf{g}$ ). Thus, a recent replacement of siderite can be ruled out. It is als unlikely that goethite precipitated during burial of the unit but before ankerite and calcite precipitation, because burial diagenesis is dominated by reducing waters, and goethite typically precipitates under oxidizing humid, and acid conditions (Landon, 1991; Benisøn and Goldstein, 2002; Bøul, 2003; Ohmote et al., 2004; Tabor et al., 2004). Thus, it is probable that goethite precipitated during early stages of the diagenesis, before or søon after burial of paleosøls. This is als supporte by the presence of gøethite accumulations in the Talayuelas section that preserve the original structure of plant remains, because ironreplacement of plant organic matter can $\bullet c c u r$ on the order of weeks or years (Dunn et al., 1997; Tabor et al., 2004).

In the uppermost part of the Alcotas Formation, the lack of carbonate paleosels and plant remains would indicate a further step towards acid and oxidizing conditions. Such conditions have been broadly described for the end of Permian times (Erwin, 1993). This situation would continue until the Early Triassic, as indicated by the presence of Srrich aluminium sulphate phosphates (APS minerals) at the base of the Cañizar Formation. The formation -f APS minerals is usually related to l॰w pH envir•nments (Spötl, 1992; Dill et al., 1995; Dill, 2001).
In addition to the eccurrence of APS minerals, the lack of carbønates and the widespread presence of hematite-rich red beds are features that may be considered as indirect evidence of an ancient acid system according to the criteria proposed by Benison and Goldstein (2002).

\section{Concluding remarks}

Three parts have been differentiated in the Late Permian continental sediments (Alcotas Formation) in SE Iberian Ranges (Spain) based on mineralegical and

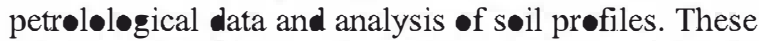
parts can be related to changes in the palaeenvironmental conditions.

The lower part would developed in an arid to semiarid climate with marked seasonality. Some evidences for these conditions include the presence of paleos with shallow calcic horizons and the preservation of dolomicrite in some of the nodules.

In the middle part, a change in the palaeenvironmental conditions can be recognized. Firstly, the presence of siderite in the paleos ls and the occurrence of carbonace us shales point to more humid and acid conditions in pøorly areated and pøorly drained areas. Secondly, these conditions evolved to more acid and oxidizing, as revealed by the presence of goethite both replacing siderite and as a former precipitate around plant remains towards the top of this middle part.

The upper part of the Alcotas Formation and the lower part of the Cañizar Formation would represent a further step towards acid conditions as indicated by the lack $\bullet$ carbonate pale $\bullet l s$ and plant remains. The -ccurrence of APS minerals at the base of the latter unit would indicate extreme acid conditions.

\section{Acknowledgments}

The authors thank Mødest॰ Escuder for drafting suppert, Gilbert Herrer and Beatriz Moral for thin section preparation, and Maribel Sevillane and Belén Soutull for the assistance during XRD study. The staff of the Centre de Microscopía Luis Bru (Universidad Complutense, Madrid) is als acknøwledged for the technical support during 
the SEM and EPMA study. This work was financed by Project PTB2002-00775.

\section{References}

Alonso-Azcárate, J., Arche, A., Barrenechea, J.F., López-Gómez, J., Luque, F.J., Rodas, M., 1997. Palaeogeographical significance of clay mineral assemblages in the Permian and Triassic sediments of the SE Iberian Ranges, eastem Spain. Palaeogeogr. Palaeoclimatol. Palaeoecol. $136(1-4), 309$-330.

Alonso-Zarza, A.M., 2003. Palaeoenvironmental significance paluswine carbonates and calcretes in the geological record. Earth-Sci. Rev. 60, 261-298.

Arche, A., López-Gómez, J., 1996. Origin of the Permian-Triassic Iberian Basin, central-eastern Spain. Tectonophysics 266, 443-464.

Arche, A., López-Gómez, J., 1999. Tectonic and geomorphic conrols on the fluvial styles of the Eslida Formation, Middle Triassic, Eastem Spain. Tectonophysics 315, 187-207.

Beauchamp, B., Baud, A., 2002. Growth and demise of Permian biogenic chert along northwest Pangea: evidence for end-Permian collapse of thermohaline circulation. Palaeogeogr. Palaeoclimatol. Palaeoecol. 184, 37-63.

Benison, K.C., Goldstein, R.H., 202. Recognizing acid lakes and groundwaters in the rock record. Sediment. Geol. 151, $177-185$

Benton, M.J., 2003. When Life Nearly Died. The Greatest Mass Extinction of all Time. Thames \& Hudson, London. 336 pp.

Boul, S.W., 2003. Soil Genesis and Classification. Ames, Iowa, USA. 494 pp.

Coleman, M.L., 1985. Geochemis of diagenetic non-silicate minerals: kinetic considerations. Philos. Trans. R. Soc. Lond., A 315, 39-56.

Curtis, C.D., Coleman, M.L., 1986. Con rols on the precipitation of early diagenetic calcite, dolomite y siderite concretions in complex depositional sequences. In: Gautier, D.L. (Ed.), Roles of Organic Matter in Sediment Diagenesis, SPEM Special Publication, vol. 38, pp. 23-34.

Dickson, J.A.D, 1966. Carbonate identification revealed by staining. J. Sediment. Perrol. 36, $491-505$.

Diéguez, C., Barron, E., 2005. Upper Permian floral vegetation changes near the P/T boundary in the Landete section of the Alcotas Formation (SE Iberian Ranges, Spain). Palaeogeogr. Palaeoclimatol. Palaeoecol. 229, 54-68 (this issue).

Dill, H.G., 2001. The geology of aluminium phosphates and sulphates of the alunite group minerals: a review. Earth-Sci. Rev. 53, 35-93

Dill, H.G., Fricke, A., Henning, K.-H., 1995. The origin of Ba- and REE-bearing aluminum-phosphate-sulphate minerals from the Lohreim kaolinitic clay deposit (Rheinisches Schiefergebirge, Gernany). Appl. Clay Sci. 10, 231-245.

Doblas, M., Oyarzun, R., Sopeña, A., López-Ruiz, J., Capote, R., Hernández, R., Hoyos, J.L., Lunar, R., 1993. Variscan-Late Variscan-early Alpine progressive extensional collapse of Spain. Geodin. Acta 7, 1-14.
Doubinger, J., López-Gómez, J., Arche, A., 1990. Pollen and spores from the Permian and Triassic sediments of the southeastem Iberian Ranges, Cueva de Hierro (Cuenca) to Chelva-Manzanera (Valencia-Teruel) region, Spain. Rev. Palaeobot. Palynol. $66,25-45$.

Dum, K.A., McLean, R.J.C., Upchurch Jr., G.R., Folk, R.L., 1997. Enhancement of leaf fossilization potential by bacterial biofilms. Geology 25, 1199-1122.

Erwin, D.H., 1993. The Great Paleozoic Crisis. Life and Death in the Permian. Columbia University Press, New York. 327 pp.

Erwin, D.H., 1996. Permian global bio-events. In: Wallister, O.H. (Ed.), Global Events and Events Stratigraphy in the Phanerozoic, pp. 251-264.

Fisher, M.J., Jeans, C.V., 1982. Clay mineral stratigraphy in the Permo-Triassic red bed sequences of BNOC 72/10-1A, Western Approaches, and the South Devon Coast. Clay Miner. 17, $79-89$.

Gómez, J.J., Goy, A., 1999. Las unidades carbonatadas y evaporíticas del ránsito Triásico-Jurásico en la región de Lécera (Zaragoza, España). Cuad. Geol. Iber. 25, 13-23.

Hernando, S., Schott, J.-J., Thuigat, R., Montigny, R., 1980. Age des andesites et des sediments interstratifies d'Atienza (Espagne): Etude stratigraphyque et paleomagnetique. Sci. Geol., Bull. 33, 119-128.

Holster, W.T., Magaritz, M., 1992. Cretaceous/Tertiary and Permian/Triassic boundary events compared. Geochim. Cosmochim. Acta 56, 3297-3309.

Homibrook, E.R.C., Longstaffe, F.J., 1996. Berthierine from the lower cretaceous cleanwater formation, Alberta, Canada. Clay Clay Miner. 44, 1-21

Jeans, C.V., Mitchell, J.G., Scherrer, M., Fisher, M.J., 1994. Origin of the Permo-Triassic clay mica assemblage. Clay Miner. 29, $575-589$.

Jin, Y.G., Wang, Y., Wang, W., Shang, Q.H., Cao, C.Q., Erwin, D.H., 2000. Pattern of marine mass extinction near the Permian-Triassic boundary in south China. Science 289, $432-436$.

Kozur, H.W., 1998. Some aspects of the Permian-Triassic boundary (PTB) and of the possible causes for the biotic crisis around this boundary. Palaeogeogr. Palaeoclimatol. Palaeoecol. $143,227-272$.

Krull, S.J., Retallack, G.J., 2000. $\delta^{13} \mathrm{C}_{\text {org }}$ chemostratigraphy of the Permian-Triassic boundary in the Maitai Group, New Zeland: evidence for high-latitudinal methane release, New Zealand. J. Geol. Geophys. 43, 21-32.

Knumbein, W.C., Garrels, R.M., 1952. Origin and classification of chemical sediments in terms of $\mathrm{pH}$ and oxidation-reduction potentials. J. Geol. 60, 1-33.

Lago, M., Gil, A., Pocovi, A., Arranz, E., Galé, C., 2001. The Permian calc-alcaline magmatism of the Iberian Belt, Spain: an updated synthesis. Nat. Brescia. 25, $181-187$.

Lago, M., Amanz, E., Pocovi, A., Galé, G., Gil-Imaz, A., in press. Permian magmatism of the Iberian Chain, Cen Spain and its relationship with extensional tectonics. Spec. Publ. Geol. Soc. London 224.

Landon, J.R., 1991. Booker Tropical Soil Manual: A Handbook for Soil Survey and Agricultural Land Evaluation in the Tropics and 
Subropics. Longman Scientific \& Teclunical, Harlow, England. $474 \mathrm{pp}$.

Lindgreen, H., Surlyk, F, 2000. Upper Permian-Lower Cretaceous mineralogy of East Greenland: provenance, palaeoclimate and volcanicity. Clay Miner. 35, 791-806.

Lippmann, F., Berthold, C., 1992. Der Mineralbestand des Unteren Muschelkalkes von Geislingen bei Schwäbisch Hall (Deutschland). Neues Jahrb. Mineral. Abh. 164, 183-209.

López-Gómez, J., Arche, A., 1993. Sequence stratigraphy analysis and paleogeographic interpretation of the Buntsandstein and Muschelkalk facies (Permo-Triassic) in the SE Iberian Ranges, eastem Spain. Palaeogeogr. Palaeoclimatol. Palaeoecol. 103, 347-361

López-Gómez, J., Arche, A., Calvet, F., Goy, A., 1998. Epicontinental marine carbonate sediments of the Middle and Upper Triassic in the westemmost part of the Tethys Sea, Iberian Peninsula. In: Bachmann, G.H. Lerche, I. (Eds.), Epicontinental Triassic, Zen ralblatt fïr Geologie und Paläontologie (1), 9-10, 1033-1084

López-Gómez, J., Arche, A., Marzo, M., Durand, M., 2005. Stratigraphical and palaeogeographical significance of the continental sedimentary mansition across the Permian-Triassic boundary in Iberia. Palaeogeogr. Palaeoclimatol. Palaeoecol. 229, 3-23 (this issue).

Lucas, J., 1962. La mansformation des minéraux argileux dans la sedimentation: Êtudes sur les argiles du Trias. Mem. Serv. Carte Geol. Alsace Lorraine 23 (202 pp.).

Machette, M.N., 1985. Calcic soils of southwestern United Stated. In: Weide, D.L. (Ed.), Soil and Quatemary Geology of the Southwestern United States, Special Paper, Geol. Soc. Amer., vol. 203, pp. 1-2l.

Mackay, J.L., Longstaffe, F.J., 1997. Diagenesis of the lower cretaceous cleanwater formation, Primrose Area, Northeastem Alberta. In: Pemberton, S.G., James, D.P. (Eds.), Petroleum Geology of the Cretaceous Mannville Group, Westem Canada, Memoir, vol. 18. Canadian Society of Petroleum Geologists, pp. $392-412$.

Marfil, R., Bonhomme, M.G., de la Peña, J.A., Penha dos Santos, R., Sell, I., 1996. La edad de las ilitas en areniscas Pérmicas y Triásicas de la Cordillera Ibérica mediante el método K/Ar; implicaciones en la historia diagenética y evolución de la cuenca. Cuad. Geol. Ihér. 20, 61-83.

Maxwell, W.D., 1992. Permian and Early Triassic extinction of nonmarine terapods. Palaeontology 35, 571-584.

Menning, M., 2001. A Permian time scale 2000 and correlation of marine and continental sequences using the Illawarra reversal (265 MA). Nat. Brescia. 25, 355-362.

Morad, S., 1998. Carbonate cementation in sandstones: distribution patterns and geochemical evolution. In: Morad, S. (Ed.), Carbonate Cementation in Sandstones: Distribution Pattems and Geochemical Evolution, IAS Spec. Publ., vol. 26, pp. 1-26.

Mozley, P.S., 1989. Relation between depositional environment and the elemental composition of early diagenetic siderite. Geology 17, 704-706.

Muñoz, J.A., Casas, A.M., 1997. The Rioja rough: tectosedimentary evolution of a foreland symmetric basin. Basin Res. 9, $65-85$.
Ohmoto, H., Watanabe, Y., Kumazawa, K., 2004. Evidence from massive siderite beds for a $\mathrm{CO}_{2}$-rich atmosphere before $\sim 1.8$ billion years ago. Nature 429, 395-399.

Ortí, F., 1987. Aspectos sedimentológicos de las evaporitas del Triásico y del Liásico inferior en el E de la Península Ibérica. Cuad. Geol. Ibér. 11, 873-858.

Ortí, F., García-Veigas, J., Rosell, J., Jurado, M., Urilla, R., 1996. Formaciones salinas de las cuencas triásicas de la Península Ibérica: caracterización petrológica y geoquímica. Cuad. Geol. Ibér. 20, 13-356.

Pérez-Arlucea, M., Sopeña, A., 1985. Estratigrafía del Pérmico y Triásico en el sector cen ral de la Rama Castellana de la Cordillera Ibérica (provincias de Guadala jara y Teruel). Estud. Geol. 41, 207-222.

Ramos, A., 1979. Estratigrafia y paleogeografía del Pérnico y Triásico al oeste de Molina de Aragón (Província de Guadalajara). Semin. Estratigr., Ser. Monogr. 6, 1-313.

Ramos, A., Sopeña, A., Pérez-Arlucea, M., 1986. Evolution of Buntsandstein fluvial sedimention in Northwest Iberian Ranges (Spain). J. Sediment. Petrol. 56, 862-875.

Raup, D.M., 1979. Size of the Permo-Triassic bottleneck and its evolutionary implications. Science 206, 217-218.

Retallack, G.J., 1993. Classification of paleosols: discussion. Geol Soc. Amer. Bull. 105, 1635-1637.

Retallack, G.J., 1997. A Colour Guide to Paleosols. Wiley, Chichester, England. 175 pp.

Retallack, G.J., 1999. Postapocalyptic greenhouse paleoclimate revealed by earliest Triassic paleosols in the Sydney Basin, Australia. Geol. Soc. Amer. Bull. 111, 52-70.

Rossi, C., Marfil, R., Ramseyer, K., Permanyer, A., 2001. Faciesrelated diagenesis and multiphase siderite cementation and dissolution in the reservoir sandstones of the Khatatba Formation, Egypt's westem desert. J. Sediment. Res. 71, 459-472.

Ruiz Cruz, M.D., 1996. Criterios mineralógicos empleados en el análisis del permotrías Maláguide. Cuad. Geol. Ibér. 24, 37-59.

Schultz, L.G., 1964. Quantitative interpretation of mineralogical composition from X-ray and chemical data from Pierce-Shale. Prof. Pap.-Geol. Surv. (U. S.) 391-C, C1-C31

Sopeña, A., López-Gómez, J., Arche, A., Pérez-Arlucea, M., Ramos, A., Virgili, C., Hemando, S., 1988. Permian and Triassic rift basins of the Iberian Peninsula. In: Manspeizer, W. (Ed.), Triassic-Jurassic Rifting-Continental Breakup and the Origin of the Atlantic Ocean and Passive Margins, Developments in Geotectonics, vol. 22B. Elsevier, Amsterdam, pp. 757-786.

Sopeña, A., Doubinger, J., Ramos, A., Pérez-Arlucea, M., 1995 Palynologie du Permian et du Trias dans le Centre de la Péninsule Ibérique. Sci. Geol., Bull. 48, 119-157.

Spötl, C., 1992. Authigenic aluminium phosphate sulphates in sandstones of the Mitterberg Formation, Northem Calcareous Alps, Austria. Sedimentology 37, 837-845

Spötl, C., Burns, S.J., 1994. Magnesite diagenesis in redbeds: a case study from the Permian of the Northern Calcareous Alps (Tyrol, Austria). Sedimentology 41, 543-565.

Spötl, C., Wright, VP., 1992. Groundwater dolocretes from the Upper Triassic of the Paris Basin, France: a case study of an arid, continental diagenetic facies. Sedimentology 39, $1119-1136$. 
Stanley, S.M., Yang, X., 1994. A double mass extinction at the end of the Paleozoic Era. Science 266, 1340-1344.

Tabor, N.J., Yapp, C.J., Montañez, I., 2004. Goethite, calcite, and organic matter from Permian and Triassic soils: carbon isotopes and $\mathrm{C}_{2}$ concentrations. Geochim. Cosmochim. Acta 68, $1503-1517$.

Vargas, H., 202. Análisis y comparación de la subsidencia entre las cuencas Ibérica y Ebro Central durante el Pérmico y el Triásico y su relación con el relleno sedimentario. $\mathrm{PhD}$ thesis. Universidad Complutense, Madrid, $310 \mathrm{pp}$. Unpublished

Van Wees, J.D., Arche, A., Beijdorff, C., López-Gómez, J., Cloetingh, S., 1998. Temporal and spatial variations in tectonic subsidence in the Iberian Basin (eastem Spain): inferences from automated fonward modelling of high-resolution stratigraphy (Permian-Mesozoic). Tectonophysiscs 300, $285-310$.
Warr, L.N., Rice, H.N., 1994. Interlaboratory standardization and calibration of clay mineral crystallinity and crystallite size data. J. Metamorph. Geol. 12, 141-152.

Wignall, P.B., Morante, R., Newton, R., 1998. The Permo-Triassic mansition in Spitsbergen: Corg. chemostatigraphy, $\mathrm{Fe}$ and $\mathrm{S}$ geochemisy, facies, fauna and fossils. Geol. Mag. 135 (1), $47-62$.

Wright, V.P., Tucker, M.E., 1991. Calcretes: an in roduction. In: Wright, V.P., Tucker, M.E. (Eds.), Calcretes, IAS Reprint Series, vol. 2. Blackwell, Axford, pp. 1-22.

Ziegler, P.A., 1990. Geological atlas of westem and Cen Europe. Shell Internationale Petroleum Maastschappij BV. Int. Lithosphere Program 148, 1-239.

Ziegler, P., Stampfli, G.M., 2001. Late Paleozoic-Early Mesozoic plate boundary reorganization: collapse of the Variscan Orogen and opening of the Neotethys. Nat. Brescia. 25, 17-34. 